\title{
CZECH TRANSPORT AND LOGISTICS COMPANIES NEED A SOPHISTICATED APPROACH TO EMPLOYEE MOTIVATION
}

\author{
Lenka Ližbetinová1, , Miluša Balková1, Petra Voláková1, Adrian Kuka²
}

\begin{abstract}
The situation on the labour market in the field of transport and logistics is strongly undersized by offering the necessary quality human resources. Acquiring and maintaining these resources creates one of the main prerequisites for the competitiveness of companies. Knowing their preferences can help not only solve the problem of gaining, retaining quality employees, but also more efficiently spend funds in this area. The aim of the article is to determine the motivational preferences of employees in the field of transport and logistics and to identify the main areas that are least fulfilled by their employers.. The article is based on the results of a questionnaire survey on a sample of 2363 respondents. Data are processed using basic descriptive statistics and Student's T-test. The results provide an overview of the employees' preferences of transport and logistics companies and problem areas in terms of satisfaction. In addition to enriching the knowledge base for the next stage of the issue, the conclusions provide companies in the field of transport and logistics with the opportunity to take a more sophisticated approach to motivating their employees and also to help acquire new ones.
\end{abstract}

Keywords transport and logistics companies, motivation, human resources management, employees, Student's Ttest

\section{INTRODUCTION}

The area of transport and logistics showed a strong crisis in the lack of quality human resources. With the advent of Industry 4.0, the demand for the structure of employee competencies also diversified (Cai et al., 2020). This trend is expected to continue after the crisis caused by Covid-19 has subsided. For example, from the point of view of mail order trade, the demand for parcel transport has increased significantly during the pandemic (Czech Transport Publishing House, 2020a). Passenger transport shows the opposite trend, with the worst situation being in air transport (Czech Transport Publishing House, 2020b). However, despite the turbulent changes, it is a precondition for the future that human resources will still be an indispensable attribute for these employers. Building an employer's brand can therefore be one of the decisive factors for their success. Therefore, knowledge of current motivational preferences provides an opportunity for employers to create a more sophisticated approach and spend money more efficiently.

The article addresses the issue of motivation for employees working for transport and logistics companies. It builds on the results of research carried out at the end of 2017 and during 2018. The research focused on the preference of motivational factors for employees of transport and logistics companies and also examined the real satisfaction with the current level of these factors in their current employment. In the

\footnotetext{
${ }^{1}$ The Institute of Technology and Business in Ceske Budejovice, Faculty of Corporate Strategy, 37001 Ceske Budejovice, Czech Republic

${ }^{2}$ Faculty of Operation and Economics of Transport and Communications, University of Žilina, 01026 Žilina, Slovak Republic

*corresponding author, phone: +420 387842 146, e-mail: lizbetinova@mail.vstecb.cz
} 
research, there were investigated motivational factors in 5 basic categories (financial evaluation, social area and benefits, working conditions, career and interpersonal relationships) with a total of 30 motivational factors. The aim of the article is to determine the motivational preferences of employees in the field of transport and logistics and to identify the main areas that are least fulfilled by their employers.

\section{CURRENT STATE OF THE PROBLEM SOLVED}

Transport and logistics companies have their own specifics resulting from the nature of the services provided. Motivating its employees is in the interest of the company (Hitka, 2015; Kucharčíková and Mičiak, 2017) due to the fact that this service is characterized by a high influence of human factors on the result and customer satisfaction because it is not possible to create it in advance at any time or store and it is created in interaction with the customer (Mateides and Dado, 2002). According to research by Jigjiddorj (2019), there is a strong relationship between satisfied employees and their loyalty.

\subsection{Human resources in the field of transport and logistics}

The global concept of supply and demand chains is linked to the ability to respond flexibly to change, ensure optimization and synchronization of activities (Nekturová, 2016). The progressive growth of output in this sector so far also causes greater openness to innovation (Koláŕ, 2016; Chocholac et al., 2020). Logistics in the Slovak Republic and the Czech Republic form part of European and global trade, and providers of these services participate in transnational production and distribution chains and are therefore also affected by global problems in this area (Nedeliakova et al., 2013; Riha et al., 2018; Motykova and Svadlenka, 2016). Strong arguments for the allocation of logistics centres in the Slovak Republic and the Czech Republic are the advantageous central location in the EU (Kampf et al., 2011), lower overhead costs and wages, or the available qualified workforce. The problem of lack of qualified, motivated and high-quality human resources in the field of transport and logistics, which has been known in most developed regions for a long time (USA, DE, GB, FRA), has spread secondarily to the Czech and Slovak environment (Logistic News, 2017). According to the Confederation of Industry and Transport of the Czech Republic (2019), the demand for employees was over 199 thousand in August 2017 and up to 300 thousand employees in 2019 (Sita, 2018; Confederation of Industry and Transport ČR, 2019). Therefore, logistics companies are beginning to consciously use the so-called employee branding and thus achieve greater attractiveness for current and potential employees (Nadanyiova, 2016; Davies et al., 2018). This approach includes progressive HR activities so that the employer proactively differentiates itself from its competition and retains and attracts as many new quality employees as possible. Of course, in order for the funds to be spent as efficiently as possible, it is essential that these programs be built on the real preferences of the target group of human resources.

\subsection{Human resources and Industry 4.0}

Today, businesses are reaching a point where their activities are being affected by the Fourth Industrial Revolution and the digitalisation associated with it (Blštáková, 2018; Roblek et al., 2016). Digitization not only affects production itself but also causes changes in the human resource management system (Cai et al., 2020). Management has new opportunities to make the management process more efficient by reducing routine work and saving time and money (Stachova et al., 2018). On the other hand, this challenge also brings a number of risks and dangers to the company and labour resources (Bagis et al., 2019). Also, management is "pushed to use" scientific, technical and organizational innovations, to evaluate them, assimilate and delegate to subordinates. The management mechanism acquires a new concept, leaders use different approaches, progressive forms of communication and techniques (Mura et al., 2017; Mura et al., 2019) and methods of personnel management are used. Managers have two difficult tasks: to make changes in themselves and at the same time to inspire and motivate others to change (Ojo, 2020). Under the influence of digitization, changes occur in both groups in a wide range of characteristics 
(Kucharčíková et al., 2018). Motivation of employees to change demanding assignments, because most of them prefer stability, and not everyone needs new knowledge and the desire to improve (Ližbetinová et al. 2018, Hitka et al., 2019). It is necessary to create a new human resource management mechanism that will allow us to realize the success of the digital economy and motivate our subjects to change aimed at the successful operation of enterprises in the new age of digital information. (Zaborova and Markova, 2019).

\section{MATERIAL AND METHODS}

The aim of the article is to present the motivational preferences of employees in the field of transport and logistics and to identify the main areas that are least fulfilled by employers. The article presents partial outputs of research (implemented in 2017 and 2018) focused on human resources management research in the environment of transport and logistics companies. The outputs of the article are based on data obtained from a questionnaire survey on a research sample of 2363 respondents (employees in the field of transport and logistics in the Czech Republic - 32.2\% women and 67.8\% men). Respondents were contacted in person (printed questionnaire) in combination with e-mail (electronic version of the document on the google forms platform). The sample of respondents was selected by stratified selection according to age, education, location and job position. Basic descriptive statistics were used for data processing and analysis, ie. quantification of basic statistical characteristics (absolute and relative abundances, mean values - weighted arithmetic mean, standard deviations, variance, standard errors and lower and upper limits of the confidence interval for the mean value). The comparison of the mean values of the investigated variables was performed by Student's unpaired T-test. The basic research question was: What are the motivational preferences of employees in the field of transport and logistics? Are their motivational preferences fulfilled? In which areas are the greatest gaps in fulfilment? Based on these questions, this research hypothesis was established:

WH1: Employees are fully satisfied with the fulfilment of individual groups of motivational factors with regard to their preferences. This hypothesis is based on the assumption that there is currently a lack of quality human resources in the labour market in the field of transport and logistics. This demand forces employers to better set up incentive programs to attract, retain and at the same time encourage human resources to perform well.

\section{RESULTS AND DISCUSION}

According to the results of weighted arithmetic averages presented in Table 1, the most preferred motivating factor is a good work team (4.46), basic salary (4.44), atmosphere at the workplace (4.42), superior approach (4.40). Job security and fair evaluation share the same position with an arithmetic average of 4.38. Within the presented arithmetic averages of the fulfilment of motivational factors at present, the standard error of the average ranges from 0.019 to 0.023 , which indicates their high interpretability. Employees are most satisfied with the fulfilment of the factors safety at work (4.645), work performance (3.606), job security (3.602), good work team (3.538), content and type of work performed (3.498) and working hours (3.487) - what are motivating factors of working conditions in addition to the factor of a good work team. On the contrary, they are least satisfied with the financial motivational factors: additional financial reward (2.987) and basic salary (3.052), as well as with job recognition (3.081) and powers such as professional factors and social benefits. Other financial rewards, basic salary and social benefits are hygienic factors (dysfactors) which, when not met, create dissatisfaction. Their fulfilment cannot in itself lead to job satisfaction, but only to the reduction or elimination of dissatisfaction. We classify factors directly related to the context of work into this group, while employees are satisfied with them in the first 5 places. Job recognition and powers belong to the group of motivational factors (satisfactors) according to Herzberg's theory (Gawel, 1996), and their fulfilment has a high impact on creating employee satisfaction. A summary comparison of the preferences 
of motivational factors and satisfaction with their fulfilment in the current job is presented in Fig. 1. From this graphic representation, it is clear that there are significant differences between the preferred and actual level of motivational factors for the basic salary (filled to 68.7\%), further financial evaluation (69.8\%) and fair evaluation (72.6\%), which are all items of the group of financial factors). The other least fulfilled are recognition (75.1\%), communication (76.4\%) and atmosphere (77.5\%) at the workplace, the approach of a superior (78.2\%) and a good work team $(79.3 \%)$.

Tab. 1 Results of evaluation of preference of motivational factors; source: authors

\begin{tabular}{|c|c|c|c|c|c|c|}
\hline No. & Motivational factors & $\mathbf{N}$ & $\begin{array}{l}\text { Arithmetic } \\
\text { average }\end{array}$ & $\begin{array}{l}\text { Standard } \\
\text { error }\end{array}$ & $\begin{array}{l}\text { Standard } \\
\text { deviation }\end{array}$ & Variance \\
\hline 1 & Atmosphere in the workplace & 2363 & 4.42 & 0.016 & 0.788 & 0.621 \\
\hline 2 & Good working team & 2363 & 4.46 & 0.016 & 0.766 & 0.586 \\
\hline 3 & Further financial evaluation & 2363 & 4.28 & 0.017 & 0.819 & 0.671 \\
\hline 4 & Physical demands of work & 2363 & 3.51 & 0.021 & 1.024 & 1.049 \\
\hline 5 & Job security & 2363 & 4.38 & 0.016 & 0.793 & 0.630 \\
\hline 6 & Workplace communication & 2363 & 4.30 & 0.017 & 0.840 & 0.706 \\
\hline 7 & Prestige / company name & 2363 & 3.74 & 0.022 & 1.054 & 1.111 \\
\hline 8 & Applying one's own abilities & 2363 & 4.07 & 0.018 & 0.863 & 0.745 \\
\hline 9 & Content and type of work performed & 2363 & 4.13 & 0.016 & 0.801 & 0.642 \\
\hline 10 & Feedback on the work result & 2363 & 3.97 & 0.018 & 0.898 & 0.807 \\
\hline 11 & Working hours & 2363 & 4.09 & 0.019 & 0.928 & 0.861 \\
\hline 12 & Working environment & 2363 & 4.08 & 0.018 & 0.878 & 0.770 \\
\hline 13 & Work performance & 2363 & 3.99 & 0.017 & 0.802 & 0.643 \\
\hline 14 & Career growth & 2363 & 3.80 & 0.020 & 0.983 & 0.967 \\
\hline 15 & Authority & 2363 & 3.66 & 0.021 & 1.002 & 1.004 \\
\hline 16 & Prestige - job position & 2363 & 3.75 & 0.020 & 0.994 & 0.989 \\
\hline 17 & Supervisor's approach & 2363 & 4.40 & 0.017 & 0.813 & 0.662 \\
\hline 18 & Independent decision-making & 2363 & 3.93 & 0.019 & 0.924 & 0.853 \\
\hline 19 & Self-realization & 2363 & 3.91 & 0.019 & 0.936 & 0.876 \\
\hline 20 & Social benefits & 2363 & 3.86 & 0.020 & 0.966 & 0.934 \\
\hline 21 & Fair evaluation & 2363 & 4.38 & 0.017 & 0.849 & 0.721 \\
\hline 22 & Workplace safety & 2363 & 4.19 & 0.019 & 0.931 & 0.866 \\
\hline 23 & Stress level & 2363 & 3.89 & 0.020 & 0.995 & 0.991 \\
\hline 24 & Vision of the company & 2363 & 3.68 & 0.021 & 1.040 & 1.082 \\
\hline 25 & Development of the region & 2363 & 3.39 & 0.023 & 1.127 & 1.271 \\
\hline 26 & Education and personal growth & 2363 & 3.84 & 0.021 & 1.019 & 1.039 \\
\hline 27 & Ecological approach of the company & 2363 & 3.67 & 0.023 & 1.132 & 1.282 \\
\hline 28 & Leisure time - relax, family & 2363 & 4.12 & 0.019 & 0.931 & 0.867 \\
\hline 29 & Recognition (working) & 2363 & 4.10 & 0.018 & 0.893 & 0.798 \\
\hline 30 & Basic salary & 2363 & 4.44 & 0.017 & 0.836 & 0.699 \\
\hline
\end{tabular}




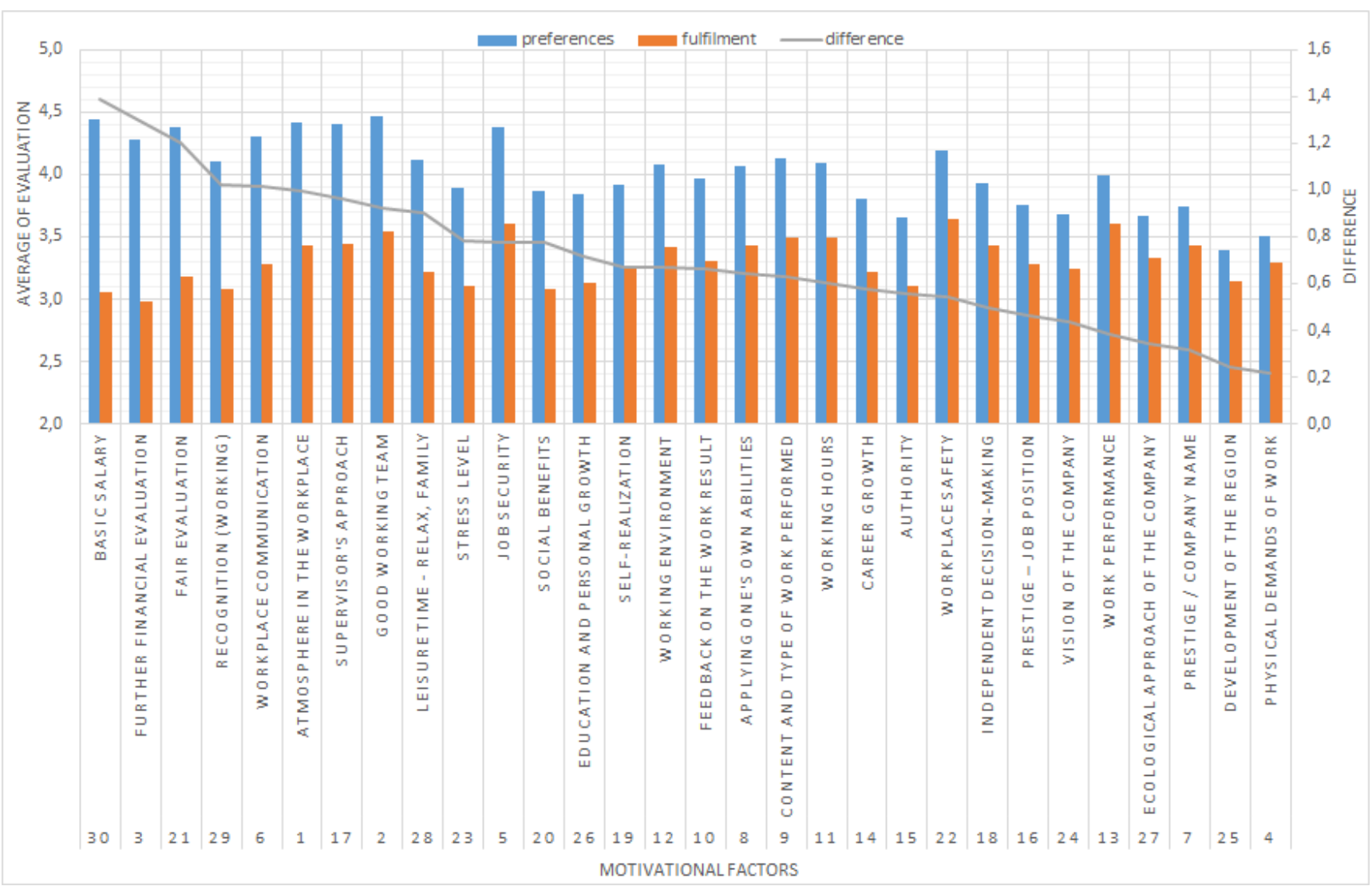

Fig. 1 Level of preferences and fulfilment of motivational factors; source: authors

In terms of the extremes of the difference between the level of fulfilment and the preference of the motivational factor by the employee, these motivational factors are identified: basic salary (difference 1.39), further financial evaluation (1.30), fair evaluation (1.20), job recognition $(1,02)$, workplace communication (1.00), superior approach (0.96) and a good work team (0.92). While it is not possible to increase financial valuation in many companies, its better connection with performance corresponds to further financial evaluation and fair evaluation. In this way, it is possible to achieve higher satisfaction without additional cost increases. Job recognition and approach of a superior is a strong opportunity to improve the motivation system, mainly due to low costs and high effect. Workplace communication and a good work team are also related to these factors. According to the results of Kampf et al. (2017). The employee's preferred trend is clan corporate culture, which is also not fulfilled.

For greater clarity, motivational factors are evaluated according to belonging to one of the 5 basic groups according to Hitka (2015) - financial evaluation (motivational factors: 3, 21 and 30), social security (motivational factors: 7, 20, 24, 25, 27, 28), working conditions (motivational factors: 4, 5, 9 to 13, 22, 23), employment (motivational factors: 8, 14 to 16, 18, 19, 26 and 29) and interpersonal relationships (motivational factors: 1, 2, 6, 17). Graph 2 presents weighted arithmetic averages for individual groups of motivational factors in terms of how important they are for employees and in terms of how they perceive their fulfilment in their current job. The value of the standard error of the average ranges from 0.012 to 0.017. For this reason, the calculated arithmetic means can be assessed as interpretable. 


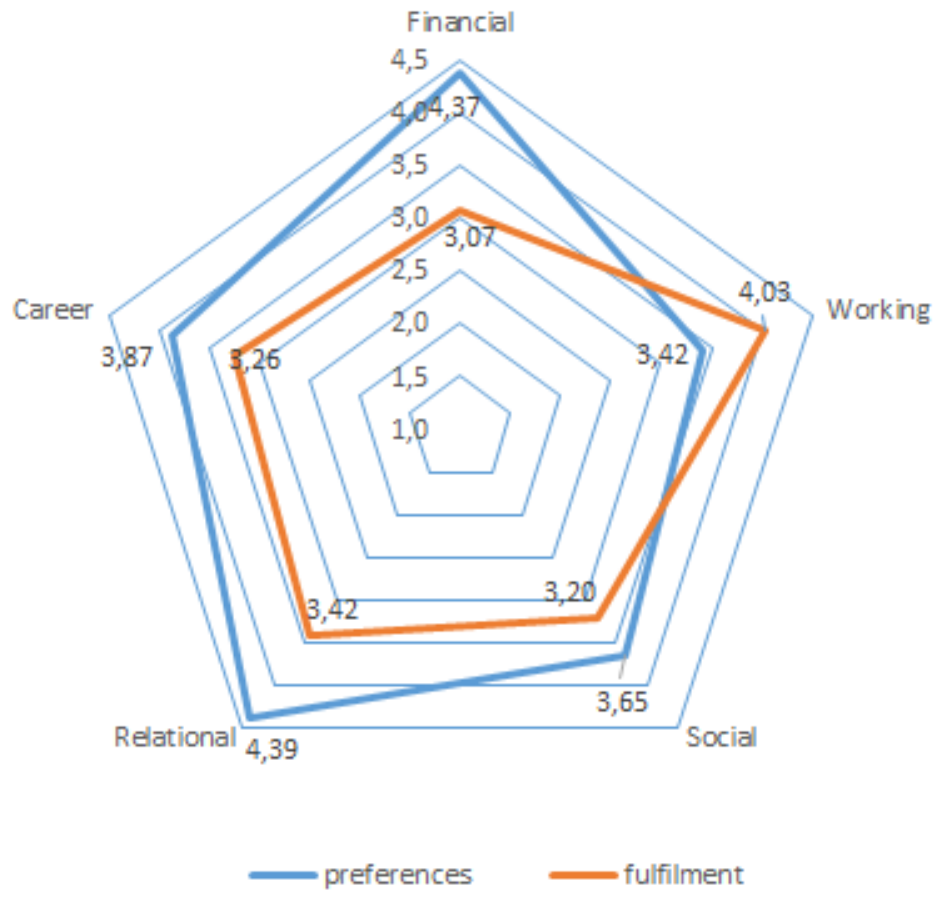

Fig. 2 Level of preferences and fulfilment of groups of motivational factors; source: authors

Tab. 2 Results of the Student's T-test; source: authors

\begin{tabular}{clllllc}
\hline $\begin{array}{c}\text { Motivational } \\
\text { groups }\end{array}$ & \multicolumn{1}{c}{ PS vs. SS } & \multicolumn{1}{c}{$\begin{array}{c}\text { Sum of } \\
\text { Squares }\end{array}$} & \multicolumn{1}{c}{ df } & $\begin{array}{c}\text { Mean } \\
\text { Square }\end{array}$ & F & Sig. \\
\hline Financial & Between Groups & 17823.886 & 1 & 17823.886 & 3273.050 & 0.000 \\
& Within Groups & 25725.253 & 4724 & 5.446 & & \\
& Total & 43549.138 & 4725 & & & \\
Works & Between Groups & 45041.917 & 1 & 45041.917 & 1426.550 & 0.000 \\
& Within Groups & 149155.683 & 4724 & 31.574 & & \\
& Total & 194197.601 & 4725 & & & \\
Social & Between Groups & 3752.120 & 1 & 3752.120 & 417.787 & 0.000 \\
& Within Groups & 42425.942 & 4724 & 8.981 & & \\
& Total & 46178.062 & 4725 & & & \\
& Between Groups & 17874.414 & 1 & 17874.414 & 2074.347 & 0.000 \\
& Within Groups & 40706.167 & 4724 & 8.617 & & \\
& Total & 58580.581 & 4725 & & & \\
& Between Groups & 35173.392 & 1 & 35173.392 & 990.251 & 0.000 \\
& Within Groups & 167794.983 & 4724 & 35.520 & & \\
\hline & Total & 202968.374 & 4725 & & & \\
\hline
\end{tabular}

Fig. 2 presents the preferences of groups of motivational factors and their current fulfilment in employment of employees of transport and logistics companies. It can be stated that relational factors and financial factors are most preferred. These groups of factors also show the largest gap in their fulfilment. For financial factors, the difference between the required performance and reality is 1.29 , and for relational ones 0.97 . The smallest demands are placed on work factors and employees are more satisfied with this group than their requirements (up to 0.62). It follows from the above, employers create suitable conditions for employees in terms of physical and mental demands, job security, content and type of work, 
working hours and free time, working hours and environment, required work performance, work safety. This may be related to the strict standards set within the EU and the lack of qualified human resources in the field of transport and logistics. The smallest deviation from the required and actual level of motivational factors is in the group of social factors (0.45), which includes social benefits, company vision, regional development and the company's ecological approach.

Table xx presents the results of Sudent's T-test, which rejects hypothesis H1. This means that for all groups of motivational factors there is a significant difference between the level of preferences and the fulfilment of motivational factors (at the level of significance $\alpha 1 \%$ ). Thus, it is proven that even in the case of a group of work motivational factors, it is significantly higher satisfaction than the employee's preferences.

From the point of view of Hezberger's theory (Table 3), higher requirements for hygienic factors (dissatisfactors) are at the level of 4.08 arithmetic average of respondents' evaluations. Their fulfilment is reached at $81.57 \%$, which may in some cases have the effect of dissatisfaction and a tendency to move towards competition. Satisfaction factors that create employee satisfaction when fulfilled are less required and their fulfilment is at the level of $84.24 \%$. According to Herzberg's theory, satisfactors are grouped in a group of career factors and dissatisfactors are a sum of groups of financial, social, relational and work factors.

Tab. 3 Preference and level of fulfilment of motivational factors according to Hezberg; source: authors

\begin{tabular}{cccccc}
\hline Type of factors & $\mathbf{N}$ & $\begin{array}{c}\text { Arithmetic } \\
\text { average }\end{array}$ & $\begin{array}{c}\text { Standard } \\
\text { error }\end{array}$ & $\begin{array}{c}\text { Standard } \\
\text { deviation }\end{array}$ & Variance \\
\hline Dissatisfactors of preferenced state & 2363 & 4.08 & 0.010 & 0.49516 & 5.149 \\
Dissatisfactors of current state & 2363 & 3.33 & 0.012 & 0.58788 & 7.258 \\
Satisfactors of preferenced state & 2363 & 3.87 & 0.013 & 0.65467 & 3.857 \\
Satisfactors current state & 2363 & 3.26 & 0.014 & 0.66965 & 4.036 \\
\hline
\end{tabular}

\section{CONCLUSIONS}

The aim of the article was to present the motivational preferences of employees in the field of transport and logistics and to identify the main areas that are least fulfilled by employers. The presented results provide an overview of motivational preferences of employees in the field of transport and logistics. This provides data for more effective motivation settings for employers. As the results show, a very strongly preferred group of motivational factors are relational and financial factors. Also, these factors have the biggest gap between preferences and fulfilment. The way is a strong connection of financial evaluation to the performance and merits of the employee, according to the analysis of individual motivational factors. This will not only increase the fulfilment of fair evaluation and additional evaluation, but also job recognition. Consequently, there are the biggest problems in terms of job recognition and manager approach. These are less costly factors, but they have a strong influence on employee motivation. The most preferred motivational factors also include the atmosphere in the workplace and a good work team, which is also according to the results of the differences between the preferred and actual state, it is necessary to focus. The results show a higher level of fulfilment of work factors compared to the required level. Knowledge of preferences in motivation and current problematic places in their fulfilment enables a more sophisticated setting of motivation in the company and thus provides a portfolio for increasing the employer's brand. This gives the employer the opportunity to gain an important competitive advantage over other companies in the field of transport and logistics. From a theoretical point of view, the results of the article provide a supplement to the knowledge base in the field of human resources management of transport and logistics companies. The results presented in the article are generalizable for transport and logistics companies in the Czech Republic. Among other things, it is necessary to take into account the 
assumption of a possible change in preferences depending on the change in external conditions. This dependence on external factors is an area for further research in this area.

\section{Acknowledgements}

This research was supported by projects: SVV202002 Trends in human resource management in transport and logistics companies, TL02000017 Inter-generation cooperation in digitalization, TL02000559 Safe cities for pedestrians and seniors and TL01000349 Stabilization and development of SMEs in rural areas.

\section{References}

Bagis, M., Karaguzel, E. S., Kryeziu L. and Ardic, K. 2019. A Longitudinal Analysis on Intellectual Structure of Human Resources Management: Theoretical Foundations and Research Trends. Journal Of Mehmet Akif Ersoy University Economics and Administrative Sciences Faculty, 6(3), pp. 796-814. DOI: 10.30798/makuiibf.569513

Cai, W.; Khapova, S.; Bossink, B.; Lysova, E.; and Yuan, J. 2020. Optimizing Employee Creativity in the Digital Era: Uncovering the Interactional Effects of Abilities, Motivations, and Opportunities. Int. J. Environ. Res. Public Health. 17, p. 1038.

Chocholac, J.; Sommerauerova, D.; Hyrslova, J.; Kucera, T.; Hruska, R. and Machalik, S. 2020. Service quality of the urban public transport companies and sustainable city logistics. Open Engineering, 10(1), pp. 86-97. DOI: 10.1515/eng-2020-0010.

Czech Transport Publishing House. 2020a. Parcel transport breaks records in the coronavirus era, GLS strengthens its main lines by purchasing new containers. Forwarding, logistics COVID-19. [online]. [Cit. 20. 20. 2020], Available at: http://www.dnoviny.cz/spedice-logistika/balikova-preprava-v-koronavirovedobe-trha-rekordy-gls-posiluje-hlavni-linky-nakupem-novych-kontejneru

Czech Transport Publishing House. 2020b. Part of Bratislava Airport serves as an aircraft parking lot. Forwarding, logistics COVID-19. [online]. [Cit. 20. 6. 2020], Available at: http://www.dnoviny.cz/leteckadoprava/cast-bratislavskeho-letiste-slouzi-jako-parkoviste-letadel

Davies, G., Mete, M., and Whelan, S. 2018. When employer brand image aids employee satisfaction and engagement. Journal of Organizational Effectiveness: People and Performance.

Gawel, J. E. 1996. Herzberg's theory of motivation and Maslow's hierarchy of needs. Practical Assessment, Research, and Evaluation, 5(1), 11. (ERIC Clearinghouse on Assessment and Evaluation Washington DC. ED421486)

Hitka et al. 2015. Differences in Motivation between Male and Female in Slovakia in 2015. Modern Applied Science; 10(1); ISSN 1913-1844

Hitka, M., Kucharčíková, A., Štarchoň, P., Balážová, Ž., Lukáč, M. and Stacho, Z. 2019. Knowledge and Human Capital as Sustainable Competitive Advantage in Human Resource Management. Sustainability, 11(18), 4985. DOI: 10.3390/su11184985

Jigjiddorj, S., Tsogbadrakh, T., Choijil, E. and Zanabazar, A. 2019. The Mediating Effect of Employee Loyalty on the Relationship between Job Satisfaction and Organizational Performance. Economics, Management and Technology in Enterprises 2019 (EMT 2019) Part of Series Advances in Economics, Business and Management Research. DOI: 10.2991/emt-19.2019.37

Kampf, R., Lorincová, S., Hitka, M. and Stopka, 0. 2017. Generational differences in the perception of corporate culture in European transport enterprises. Sustainability, 9(9), 1561.

Kampf, R.; Průša, P. and Savage, C. 2011. Systematic location of the public logistic centres in Czech Republic. Transport. 26(4), pp. 425-432; DOI: 10.3846/16484142.2011.635424. 
Kolar, V. 2016. DHL reveals key logistics trends for the next ten years. Logistics. [online]. [Cit. 25. 4. 2019.] Available at: https://logistika.ihned.cz/c1-65373790-dhl-odhaluje-klicove-logisticke-trendy-pronadchazejicich-deset-let

Kucharčíková, A. and Mičiak, M. 2017. Human Capital Management in Transport Enterprise. In Proceedings of the 18th International Scientific Conference on LOGI, Ceske Budejovice, Czech Republic, OCT 19, 2017, MATEC Web of Conferences, 134, Article Number: 00030, DOI: 10.1051/matecconf/201713400030

Kucharčíková, A.; Mičiak, M. and Hitka, M. 2018. Evaluating the effectiveness of investment in human capital in e-business enterprise in the context of sustainability. Sustainability (Switzerland). 10(9); DOI: $10.3390 /$ su10093211

Ližbetinová, L., Hitka M. and Kleymenov, M. 2018. Motivational preferences of employees in requirements of Czech and Russian transport and logistics enterprises. Nase More, 65(4 Special issue), pp. 254-258. DOI: 10.17818/NM/2018/4SI.17

Logistic News. 2017. In the Central European area, the global problem of people's scarcity is troubling logistic. [online]. [Cit. 25. 12. 2019.] Available at: http://www.logisticnews.eu/logistic-news/vestredoevropskem-prostoru-trapi-logistiku-glo

Mateides, A. and Ďad'o, J. 2002. Services: service theory: service marketing: quality in services: customer service and measuring customer satisfaction. Bratislava: Epos. ISBN 8080574529

Motykova, J. and Svadlenka, L. 2016. Statistical Analysis and Forecasting of Rail Transport Accidents in the Czech Republic. In SGEM 2016, BK 2: Political Sciences, Law, Finance, Economics and Tourism Conference Proceedings. vol. V. 2016.

Mura, L., Gontkovicova, B., Dulova Spisakova, E. and Hajduova, Z. 2019. Position of Employee Benefits in Remuneration Structure. Transformations in Business \& Economics, Vol. 18, No 2 (47), pp. 156-173. ISSN $1648-4460$

Mura, L., Ključnikov, A., Tvaronavičienè, M. and Androniceanu, A. 2017. Development trends in human resource management in small and medium enterprises in the Visegrad Group. Acta Polytechnica Hungarica, 14(7), pp. 105-122. DOI: https://doi.org/10.12700/APH.14.7.2017.7.7

Nadanyiova, M. 2016. Global Trends of the Personnel Marketing in Service Enterprises. Proceedings of the 16th International Scientific Conference on Globalization and its Socio-Economic Consequences Location: Rajecke Teplice, SLOVAKIA Date: OCT 05-06, 2016, pp. 1474-1481.

Nedeliakova, E.; Dolinayová, A. and Nedeliak, I. 2013. Methods of quality evaluation of transport services. 1st ed.; EDIS - University of Žilina, Slovakia, p. 184.

Nekturová, V. 2016. Influence of globalization trends on storage. Logistic News 2016. [online]. [cit. 30.5.2019] Available at: http://www.logisticnews.eu/logistic-news/vliv-globalizacnich-trendu-naskladovani

Ojo, 0. 2020. The Role of Human Resource in Achieving Sustainable Development. International Review of Busieness and Social Science, 1(1), pp. 11-23.

Riha, Z.; Nemec, V. and Sousek, R. 2018. Transportation and environment-economic research. WMSCI 2014 - 18th World Multi-Conference on Systemics, Cybernetics and Informatics, Proceedings. 2, pp. 212-217.

Roblek, V.; Meško, M. and Krapež, A. 2016. A Complex View of Industry 4.0. SAGE Open, 6(2). DOI: $10.1177 / 2158244016653987$

Sita. 2018. Employment of foreigners in Slovakia will be easier, the amendment also supports moving to work. [online]. [Cit. 20.11.2019.] Retrieved from: https://www.webnoviny.sk/zamestnavanie-cudzincovna-slovensku-bude-lahsie-novela-podporuje-aj-prestahovanie-za-pracou/ 
Stachova, K., Stacho, Z., Blstakova, J., Hlatká, M. and Kapustina, L.M. 2018. Motivation of Employees for Creativity as a Form of Support to Manage Innovation Processes in Transportation-Logistics Companies. Naše More, 65(4), 180-186. DOI 10.17818/NM/2018/4SI.3

Svaz průmyslu a dopravy ČR. 2019. Trh práce je vyčerpán. Firmy marně hledají přes 346 tisíc lidí. [online]. [Cit. 25. 12. 2019.] Available at: https://www.spcr.cz/pro-media/tiskove-zpravy/12845-trh-prace-jevycerpan-firmy-marne-hledaji-pres-346-tisic-lidi

Zaborova, E. and Markova, T. 2019. Modern Human Capital Management Trends in Russian SMEs. In Economics, Management and Technology in Enterprises 2019 (EMT 2019). Atlantis Press. 